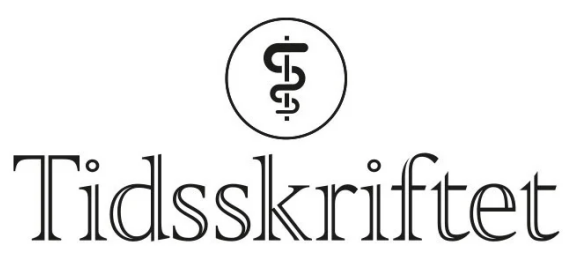

DEN NORSKE LEGEFORENING

\title{
E. Kinge svarer
}

\author{
KOMMENTAR \\ EINAR KINGE \\ ek@sandvikanevrosenter.no \\ Einar Kinge er spesialist i nevrologi ved Sandvika Nevrosenter - avtalespesialistene. \\ Forfatteren har ikke oppgitt noen interessekonflikter.
}

Helge Waal er kritisk til at jeg i min leder anbefaler opioider som behandling til pasienter med rastløse bein som ikke responderer på dopaminagonister eller alfa-2-delta-ligander. Jeg er selvsagt enig i at bruk av opioider skal være begrenset av hensyn til risiko for misbruk.

Problemet med behandling av rastløse bein med dopaminerge medisiner kan være avtakende effekt og $\varnothing$ kende symptomer. Videre responderer en del pasienter utilfredsstillende på alfa-2-delta ligander på grunn av manglende effekt og nedsatt toleranse. Derfor kan pasientene ende opp med et sterkt symptom trykk med betydelig konsekvenser for psykisk helse, livskvalitet og funksjonsnivå.

Som praktiserende nevrolog har jeg behandlet et betydelig antall pasienter med uttalte rastløse bein symptomer i snart 20 år. Hos et fåtall med behandlingsresistens har jeg ikke funnet noen annen utvei enn å foreskrive et kombinasjonspreparat med oksykodon + naloxon i lav dose, oftest som tilleggsbehandling, eventuelt som monoterapi. Dette er i tråd med europeiske retningslinjer (11). Pasientene har gjennomgående respondert godt. Mange var i utgangspunktet kritiske til å bli satt i behandling med opioider, og det har etter min erfaring ikke vært problemer med misbruk eller avhengighet hos pasientene som har fått tett oppfølging.

Jeg mener derfor at det er god legekunst å benytte oksykodon + naloxon i lav dose som et tredje behandlingsalternativ til et lite mindretall pasienter hvor man ikke har andre behandlingsmuligheter. Antallet vil uansett være beskjedent, og min bekymring for at det skal utløse misbruk er liten. Behandling med opioder i behandlingsresistente tilfeller anbefales som nevnte i europeiske retningslinjer (1) , og kombinasjonspreparat med oksykodon + naloxon er godkjent i Norge.

\section{LITTERATUR}

1. Garcia-Borreguero D, Silber MH, Winkelman JW et al. Guidlines for the first-line treatment of restless legs syndrome/Willis-Ekbom disease, prevention and treatment of dopaminergic 
augmentation: a combined task force of the IRLSSG, EURLSSG, and the RLS-foundation. Sleep Med 2016; 21:1-11. [CrossRef]

Publisert: 10. januar 2022. Tidsskr Nor Legeforen. DOI: 10.4045/tidsskr.21.0865

(C) Tidsskrift for Den norske legeforening 2023. Lastet ned fra tidsskriftet.no 26. april 2023. 